\title{
ANALYSING LOCATION ATTRIBUTES WITH A HEDONIC MODEL FOR APARTMENT PRICES IN DONETSK, UKRAINE
}

\author{
Marko KRYVOBOKOV $1 \bowtie$ and Mats WILHELMSSON ${ }^{2}$ \\ 1 Royal Institute of Technology, Section of Real Estate Planning and Land Law, Stockholm, \\ Sweden and Donetsk National Technical University, Section of Geoinformatics and Geodesy, \\ Artyoma Str. 58, 83000 Donetsk, Ukraine \\ E-mail: k_mark@ukr.net \\ 2 Royal Institute of Technology, Section of Building and Real Estate Economics, Brinellvägen 1, \\ S-100 44 Stockholm, Sweden \\ E-mail: matsw@infra.kth.se
}

Received 13 December 2006; accepted 22 June 2007

\begin{abstract}
A hedonic model is specified for asking prices for apartments in Donetsk (Ukraine). This model is used to determine statistically significant location attributes. These attributes can be used for land assessment in a city where data on the land market are lacking. Distance gradients for CBD accessibility are investigated in different geographical directions. Separate models are created for sub-samples located inside and outside the city centre. A spatial weight matrix is used to detect spatial autocorrelation. The regression results are compared with the valuation of experts.
\end{abstract}

KEYWORDS: Location attributes; Land assessment; Apartment prices; Regression; Donetsk

\section{INTRODUCTION}

In Ukraine, land, whether urban or rural, is taxed, while buildings and structures are not. However, in most Ukrainian cities the market for land is underdeveloped. There are few land sales, and many of them involve land sold by the city to the private sector. For example, according to Thomas (2003), there is effectively no secondary market for land in Kiev. Therefore, the assessed value of urban land in Ukraine is not based on market principles (Thomas, 2003). Instead, according to "Pattern of technical documentation of monetary valuation of land" (1998), assessed value depends on a weighted average of several location attributes. Valuers, land managers, and urban planners choose these location attributes and weights of their relative importance based on subjective judgements.

The process of property assessment can be recognised as "quite subjective" even in countries with a long history of property taxation (Cornia and Slide, 2005). The problem of subjectivity in land assessment in Ukraine is described in detail in Kryvobokov (2004). To increase the degree of objectivity in the specification of a model, he proposes that a list of the most important location attributes that influence values in well-developed foreign real

International Journal of Strategic Property Management ISSN 1648-715X print / ISSN 1648-9179 online (C 2007 Vilnius Gediminas Technical University http://www.ijspm.vgtu.lt 
estate markets be used in Ukraine. Boyle and Kiel (2001) and Sirmans et al. (2005) are the examples of recent review papers dealing with identification of the property characteristics, which are the most frequently used in hedonic pricing models.

Kryvobokov (2005a) estimates weights for the location attributes for the city of Donetsk, Ukraine, using the expert valuation methods: the Analytic Hierarchy Process (AHP) and a direct questionnaire.

In this paper, an alternative method is applied. We use a regression model for apartment prices in Donetsk employing the location attributes suggested previously. Thus, hedonic analysis is applied as an existing technique. The paper represents a case study of the apartment market in a particular city in Ukraine.

The aim of the paper is to derive the weights of the relative importance of location attributes that influence the market values of apartments in Donetsk. We then compare these weights with the results of expert valuations. They could also be used to specify a model for land assessment in Donetsk. Apartment prices are more relevant, as well as more market oriented, than expert valuation methods, especially for residential land (Kryvobokov, 2004). We are following Colwell (1990) in that we are using apartment prices instead of land values. In the words of Colwell (p. 117), "By shifting the other property characteristic variables, it is possible to obtain predictions of land values alone".

Roseman (2002) reviews the history and background of the Kiev housing market. Though Kiev is the focus, some features are common for apartment markets in all Ukrainian cities, like the privatisation process, the municipal ownership of common areas in residential buildings, and the presence of large residential districts in the suburban areas.

Donetsk is a city with population of over a million people. It is one of the biggest regional centres in the eastern part of Ukraine. The apartment market is well developed in Donetsk. Development was encouraged by the privatisation of the housing stock in the 1990s, during which private ownership of apartments was assigned. Now there are more than twenty real estate agencies in Donetsk, and the number is still growing.

In Section 2, we specify the hedonic model including data collection and representation. Section 3 contains the empirical analyses, both descriptive and econometric. We present our estimates of weights and a comparison between regression results and expert valuations in Section 4. The conclusions are in Section 5.

\section{MODEL SPECIFICATION}

\subsection{Hedonic modelling}

In the general hedonic model the dependent variable is price and the independent variables are real estate attributes and location attributes if the sample is cross-sectional. The estimated parameters can be interpreted as the willingness to pay (WTP) for the different attributes in question (Rosen, 1974). As formulated in Janssen and Söderberg (1999, p. 361), "the theory of hedonic price functions provides a framework for the analysis of differentiated goods like housing units whose individual features do not have observable market prices".

Regression is also widely used in investigations of apartment prices around the world (Asabere and Huffman, 1996; So et al., 1997; Watkins, 1998; De Cesare and Ruddock, 1998; Branas-Garza et al., 2002; and Björklund and Klingborg, 2005, for example). Researchers in Ukraine have also started to apply regression in real estate valuation (Sivets, 2001; Sivets and Levykina, 2003).

There is no agreement in the literature on the best functional form for the hedonic models. Rosen (1974) stressed that economic theory fails to indicate any particular form as being appropriate. The problem is discussed in 
Söderberg and Janssen (2001), Gloudemans (2002), and O'Connor (2002). According to O'Connor (2002), though all three models (additive, multiplicative, and non-linear) produce excellent results, the multiplicative model obtains the best results, and the hybrid model offers a better representation of appraisal principles. Halvorsen and Pollakowski (1981) and Wilhelmsson (2002) use a flexible multi-parameter Box-Cox model to find the best-fitting transformation. However, as a linear model describes the relationships more clearly in general and its results are easier to compare with the expert valuations, the focus of our attention is on this type of model even though we compare our results with results from the loglinear model. Hence, in our econometric modelling, two types of ordinary least square (OLS) models are specified: linear and log-linear.

A useful tool to supplement regression analysis is GIS, which not only allows us to visualise data, but also provides spatial analysis and additional data collection. GIS is widely used in real estate research, particularly in studies of apartment markets (Bible and Hsieh, 1999; Pavlov, 2000; Ward et al., 2002). Here, we use it mainly as a tool to estimate distances.

As Wiltshaw (1996) argues, if the resulting spatial pattern is not random the conclusions are likely to be flawed. Two types of spatial effect exist: spatial dependency and spatial heterogeneity. However, according to De Graaff et al. (2001), due to difficulties in separating them and for other reasons they should be handled jointly. Spatial dependency in a regression model can be detected with either the spatial weight matrix or the direct specification of the covariance matrix (Dubin, 1998). The weight matrix is widely applied in real estate analysis (e.g. Pace et al., 1998; Dubin et al., 1999; Wilhelmsson, 2002). We use Moran's I, the definition of which can be found in Dubin (1998). It is calculated with the row standardized weight matrix of inverse square distances and is empirically estimated in e.g. Bogdon and
Can (1997), De Graaff et al. (2001), Wilhelmsson (2002), and Wilhelmsson (2004). We measure distances using GIS.

\subsection{Data}

The information available is either the asking prices or the official sale prices. However, in the official register, data on apartment sale prices do not reflect realistic market prices. As the transaction fee depends on the official sale price, there is a strong incentive to register a lower price than the price actually paid.

Real estate agencies and private persons regularly publish asking prices for apartments in special newspapers and magazines in Donetsk. In this paper, we use the asking price as a dependent variable. Systematic errors in measuring asking price will not only affect the error term, but will also cause bias in the estimates. Costello and Watkins (2002) highlight that the use of asking prices, which diverge from transaction prices by different degrees, can lead to erroneous conclusions. However, asking prices are regressed in many studies analysing residential market, e.g. Henneberry (1999) in Sheffield, Yang (2001) in Beijing and Björklund and Klingborg (2005) in Sweden. Costello and Watkins (2002) call the use of asking prices an established tradition in UK housing research. In the current paper, it is a reasonable option.

In Donetsk, the largest number of sale proposals was found in the newspaper Real Estate from Hallo! Only one issue was selected, as our research is not intended to analyse movement of prices over time. The selected issue was published in February 2005.

In Donetsk, apartments are not sold by auction and purchasing prices are rarely higher than asking prices. However, the opposite situation is possible, i.e. after negotiation, the purchasing price may be lower than the asking price. In the newspaper, the asking prices are divided into two groups: those, for which price 
negotiation is possible, and those, for which the asking price is the final price. We selected the latter group for our analysis. Undoubtedly, this does not mean that all asking prices will be equal to the sale prices in reality, but it is logical to suppose that they are closer to the sale prices than the former group. This also reduces the problem of a systematic measurement error in the dependent variable. All prices are stated in US dollars.

Data include the approximate location of the apartment and internal apartment characteristics. The approximate location means a street name and/or the nearest reference object like a shop or a crossroad. The publication of approximate location instead of actual address can be explained by two reasons. In the beginning of the selling process, real estate agencies try to prevent direct contact between a buyer and a seller without their brokerage. The high crime rate is another reason why sellers do not want to publish their precise location.

As in Roseman (2002), it is important to note that the number of rooms in an apartment in Ukraine means bedrooms and living rooms. Thus, a two-room apartment includes a bedroom, a living room, a kitchen, a bathroom, and a toilet. The last two items may be in separate premises or one combined, but this information is not available. Two-room apartments were selected as typical for Donetsk and there is generally less difference in total area among them compared with one-, three-, and four-room apartments.

Published data also include information about the following characteristics of apartments: floor level, number of floors in the building, existence of a wired telephone, total area, living area, existence of a balcony and/or loggia, as well as an indication of condition. There are seven possible conditions:

1) Repair is needed;

2) Satisfactory;

3) Cosmetic repair is needed;

4) Normal;
5) Good;

6) Perfect;

7) "Euro-renovation."

Plastered walls and ceilings, new windows with plastic frames, etc., usually characterise the seventh type. This type corresponds to "Western standard" apartments described by Roseman (2002).

Only apartments in five- and nine-storey buildings are selected in the study. These buildings are the most typical in Donetsk and they are located in all districts in the city. Five-storey buildings were constructed mainly in the 1950s and 1960s while nine-storey buildings are relatively new. The latter were mainly built in the 1970 s and 1980 s, up until the collapse of the USSR. In the 1990s there was only a small amount of housing built in Donetsk, mainly elite dwellings. In recent years, many construction companies have started to construct new multifamily buildings, mainly upper class apartments.

After the review of the published information the apartments with missing data were excluded. Several apartments have extremely high asking prices compared to similar apartments in the same locations. Two reasons can explain this phenomenon. Either these apartments have excellent interior standards after repair or the sellers are asking unrealistically high prices. Apartments with atypical high asking prices were not included into the sample. A more sophisticated approach could be applied, as in O'Connor (2002), where the regression model was run and the records with the lowest and highest 2.5 percent of the estimate-to-sale ratios within each neighbourhood were removed from the sample. In this research, however, the sample is not very big, and therefore, this approach is not used.

Thus, we include 325 apartments with asking prices in our study. Our database thus contains the asking price, approximate location, and seven internal apartment characteristics: floor number (one to nine, because there is no 
concept of ground floor in residential buildings in Ukraine), the number of floors in the building (five or nine), telephone ( 1 or 0 ), total area (in square meters), balcony and/or loggia (1 if there is either a balcony or a loggia, 2 if there are both, 0 if neither), and an indicator of condition.

The variables for floor number, the number of floors in the building, telephone, and condition types can be represented as dummies. In Donetsk, the first and the top floors are usually considered the worst. First floor apartments are associated with higher risk of burglary and noise, and top floor apartments with a possible poor condition of the roof (Roseman, 2002 highlights the fact that repairs and maintenance of residential buildings in Ukraine are often lacking due to the state of municipal governments owning the common areas in the buildings). For this reason we have introduced two dummy variables, one indicating the first floor ( 1 for the first floor, 0 for the other floors) and one the top floor ( 1 for the top floor, 0 for the other floors). The expected implicit prices are negative. We also use a dummy for the number of floors: 0 for older five-storey buildings and 1 for newer nine-storey buildings. The five-storey buildings of the 1950s were built with bricks and are mostly of better quality than those of the 1960s built with pre-fabricated concrete panel blocks. However, data on age and material are not available. Using the worst type for condition as the default value, we have six dummies corresponding to types 2 to 7 .

All the apartments in the sample were placed as points on the vector map of Donetsk using ArcView GIS (Figure 1). The map provided by the Department of Master Plan of Donetsk contains dwelling blocks, major roads, commercial objects, water objects, green areas, etc. As the approximate location of the apartment was known, it was possible to recognise the city block or, at least, the group of blocks,

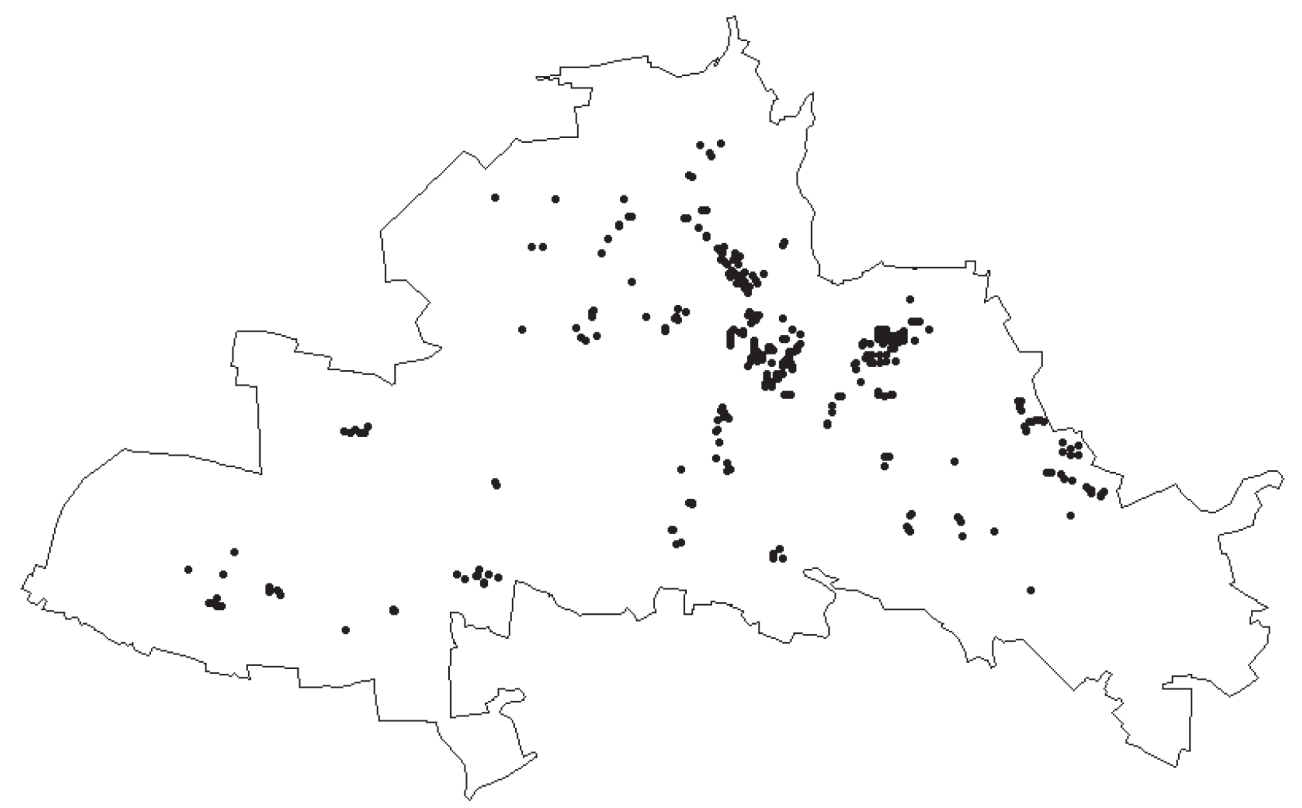

Figure 1. Location of 325 apartments within the city of Donetsk 
where the corresponding five-storey or ninestorey building is located. We always placed the point at the geometrical centre of the block (or of a central block, if there were several possible blocks).

The location attributes we use are:

- the accessibility to the CBD;

- the accessibility to the nearest secondary centre;

- the accessibility to the nearest public transportation stop;

- the accessibility to the railway station;

- the accessibility to water (the river, ponds) and green area;

- nuisance proximity;

- prestige.

Different methods can be used to recognise the CBD. Söderberg and Janssen (2001) use different locations of the CBD and select those, for which the regression result is the best. Kryvobokov (2005b) applies GIS to estimate each block's accessibility to all business and commercial objects and considers the block with the best accessibility as the CBD. In this paper, we do not apply any such methods. The central point of the central square, usually considered to be the centre of Donetsk, is used as the CBD.

The secondary centres are areas outside the CBD, which have relatively high concentrations of business and commercial development, and are usually also transport junctions. We selected secondary centres on the basis of data from the Department of Master Plan of Donetsk on the centres of administrative districts; we chose additional secondary centres using the expert approach. Again, we use the central points of these areas. The centres are shown in Figure 2, in which the CBD is indicated by a point and the thirteen secondary centres by asterisks.

The contour lines for apartment asking prices are also presented in Figure 2. They were created with the Inverse Distance

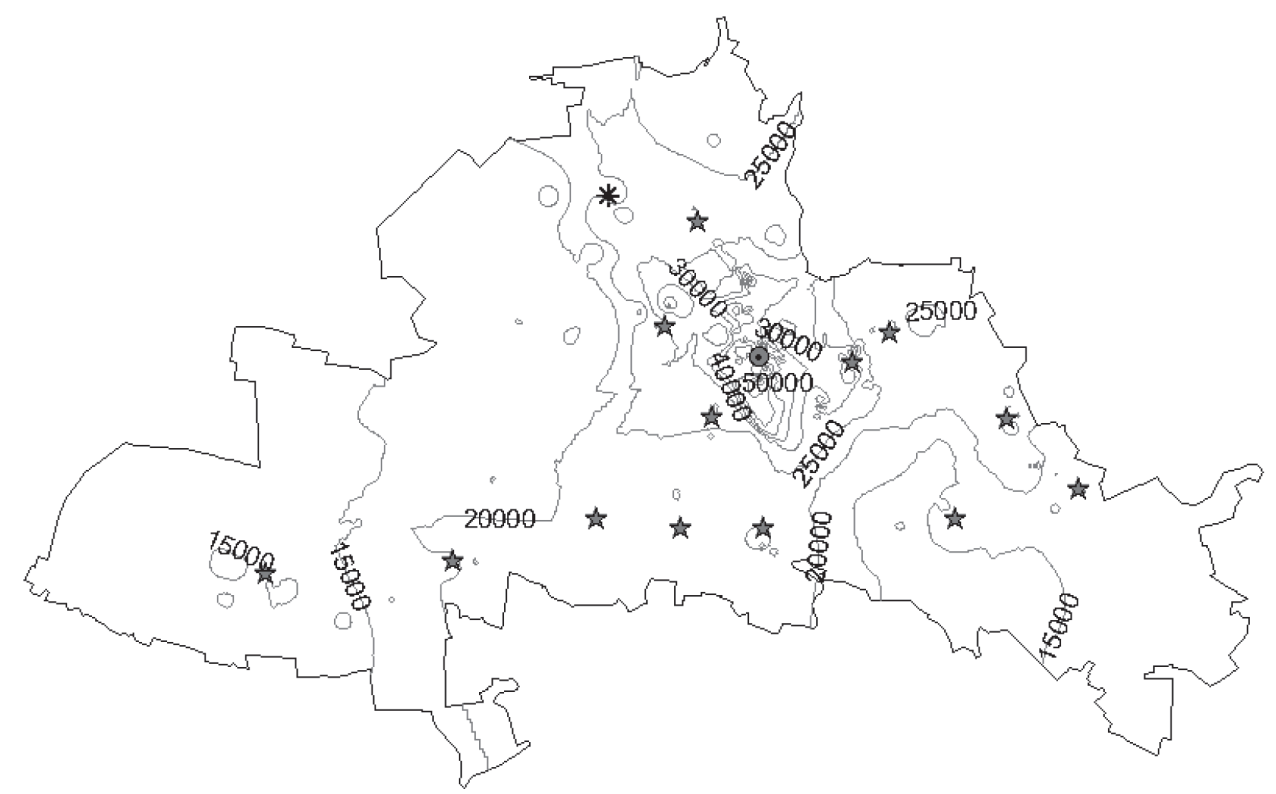

Figure 2. Locations of the CBD, the secondary centres, the railway station, and contour lines for asking prices 
Weighted method of Spatial Analyst, with nearest 12 neighbours, power 2, and no barriers. The contour lines demonstrate that the most expensive apartments are situated around the CBD. At the same time, there are apartments with the highest condition variable, i.e. where a "Euro-renovation" has been done, in almost all city districts. Distance from the CBD is characterised by a reduction in prices, though it differs in different directions. Thus, prices decrease more slowly towards the north and east from the centre than towards the west, south and southeast. The influence of several secondary centres on the configuration of contour lines in Figure 2 can be noted as well.

We use the city map to evaluate the variables for the nearest public transportation stop, the railway station, water and green area accessibility, and nuisance proximity. A public transportation stop is the location of a stop for inner public transport: buses, trolleybuses, trams, and service routes. The main railway station for the regional and inter-regional railway is considered (a "snowflake" in the northern west in Figure 2). The water objects are the attractive ponds and the river. Green areas are the main parks. We merge water objects with green areas into one variable, because the best parks in Donetsk are located close to water. Contaminating factories and slagheaps are the objects of nuisance. As a consequence of more than a century of coal mining activity, which continues, there are more than a hundred slagheaps in Donetsk. They are located in all districts of the city and are considerable sources of air pollution in the form of dust.

Prestige is included as a dummy variable for location in a prestigious area, which can be considered as a kind of sub-market. These areas are mainly the city centre, and to a lesser degree just north and east of it. In principle, it would be possible to use income level of population instead of prestige, but such statistical data is not available. The attribute of prestige is used in real estate literature, e.g. Sivitanidou (1995 and 1996) in regression modelling and Kauko (2002) in Analytic Hierarchy Process.

Distances to the CBD, a secondary centre, a public transportation stop, and the railway station were measured as the shortest paths along the road network. We measured distances to nuisances and water (green area) along straight lines, because in these cases the physical influence and view are important. When measuring distances to an object, e.g. to a green area, we used the nearest boundary point of the object. All distances were measured with GIS in kilometres $(\mathrm{km})$ and were rounded to $0.1 \mathrm{~km}$. Approximate location of apartments leads to errors when measuring distances. Systematic measurement errors would create bias in the estimates. However, in our case these errors are unsystematic.

\section{EMPIRICAL ANALYSIS}

\subsection{Descriptive analysis}

In Table 1, we show the descriptive statistics for all variables. In the sample, 48 percent of the apartments are located either on the first or on the top floor (variables Floor 1 and Floor $T$ ). The fact that these apartments are proposed for sale more often may indicate that they are usually of lower quality than apartments on other floors. There are 201 observations of five-storey buildings and 124 of nine-storey buildings (Build). Average total area (Area) is less than 50 square meters with a standard deviation as low as 6 square meters. However, this is not surprising as only two-room apartments were selected. All distance variables have high variations around their mean values. 145 apartments (45 percent) are located within the prestigious area (Prest).

Correlation coefficients are presented in Table 2. Among the internal apartment variables, Area and dummy for a wired phone connection (Phone) have the highest correlation 
with apartment price (Price). Among the condition dummies (Cond2 to Cond7), Cond7 has the highest correlation with Price, though in absolute terms this relationship is weak. All location variables except distance to a secondary centre (DSCent) and to lesser degree distance to a public transportation stop (DStop) are highly correlated with Price. The highest correlation with Price is observed for distance to the CBD (DCBD) and Prest. All distance variables, except distance to nuisance (DNuis), are negatively correlated with Price. Among the independent variables, the highest correlation is observed between $D C B D$ and distance to railway station (DRail) (0.70). This can be explained by the fact that the way from the eastern part of Donetsk to the railway station passes through the CBD. The areas closer to the CBD have better accessibility to water and parks; the corresponding correlation coefficient is 0.63 . These two facts can explain the high positive correlation coefficient (0.63) between distance to water and green area (DWater) and DRail. Naturally, DCBD and Prest are highly negatively correlated (-0.68).

\subsection{Econometric analysis}

As the aim of the paper is to estimate the weights of location attributes, no variables have been excluded from the hedonic price equation, even though the correlation between several of the independent variables is high. However, we will test for multicollinearity in regression models.

As a first step in measuring the relative importance among the location variables, apartment prices were regressed on measured

Table 1. Descriptive statistics

\begin{tabular}{llllll}
\hline Variable & Description & Mean & $\begin{array}{l}\text { Standard } \\
\text { deviation }\end{array}$ & Minimum & Maximum \\
\hline Price & Asking price, USD & 26,042 & 9,911 & 9,000 & 60,000 \\
Floor1 & Dummy for first floor & 0.24 & 0.43 & 0 & 1 \\
FloorT & Dummy for top floor & 0.24 & 0.43 & 0 & 1 \\
Build & Dummy for five- and nine-storey building & 0.38 & 0.49 & 0 & 1 \\
Phone & Dummy for phone & 0.80 & 0.40 & 0 & 1 \\
Area & Total area, m ${ }^{2}$ & 48 & 6 & 36 & 91 \\
Balc & Rank of 0 to 2 for balcony/ loggia & 0.87 & 0.47 & 0 & 2 \\
Cond2 & Dummy for condition 2 & 0.19 & 0.39 & 0 & 1 \\
Cond3 & Dummy for condition 3 & 0.05 & 0.22 & 0 & 1 \\
Cond4 & Dummy for condition 4 & 0.23 & 0.42 & 0 & 1 \\
Cond5 & Dummy for condition 5 & 0.31 & 0.46 & 0 & 1 \\
Cond6 & Dummy for condition 6 & 0.07 & 0.26 & 0 & 1 \\
Cond7 & Dummy for condition 7 & 0.06 & 0.23 & 0 & 1 \\
DCBD & Distance to the CBD, km & 5.84 & 4.72 & 0.1 & 20.4 \\
DSCent & Distance to the nearest secondary centre, km & 1.85 & 1.48 & 0.1 & 9.3 \\
DStop & Distance to the nearest stop, km & 0.26 & 0.16 & 0.1 & 1.0 \\
DRail & Distance to the railway station, km & 9.91 & 5.12 & 0.3 & 22.1 \\
DWater & Distance to water (green area), km & 1.29 & 0.82 & 0.1 & 3.6 \\
DNuis & Distance to the nearest nuisance, km & 0.97 & 0.51 & 0.1 & 2.4 \\
Prest & Dummy for prestigious area & 0.45 & 0.50 & 0 & 1 \\
\hline
\end{tabular}




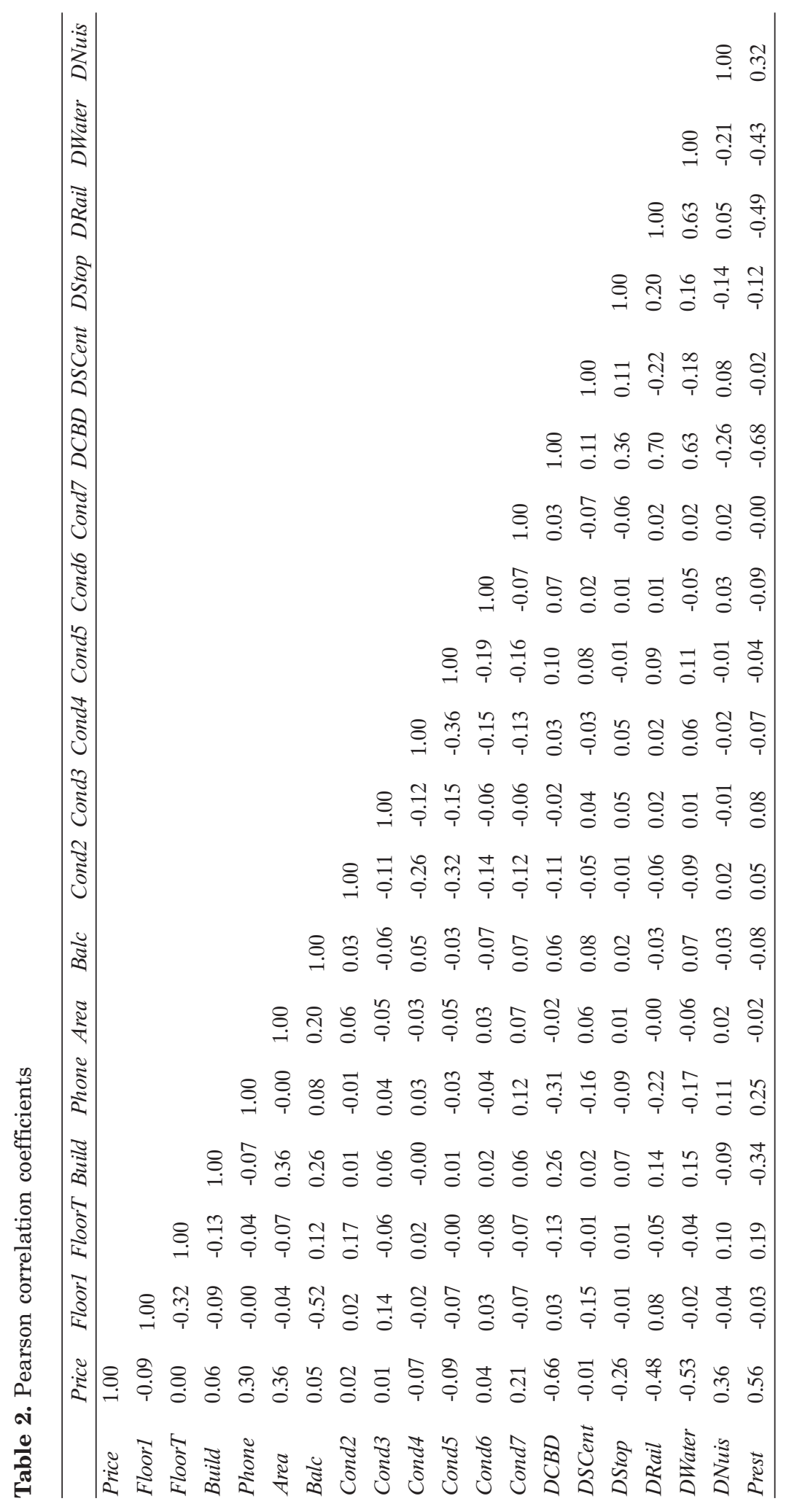


apartment attributes and all location attributes, denoted LIN (the linear model) and $L O G$ (the log-linear model) in Table 3. Model $L O G$ has higher adjusted $\mathrm{R}^{2}$ than model $L I N$ (77 percent compared to 69 percent). In both models, Build, Area, Cond6, Cond7, DCBD, and Prest are statistically significant. Cond5 is significant in model LIN, whereas FloorT and Phone are significant in model LOG. Where the location attributes are concerned, DWater and DNuis are significant only in model LIN, whereas DSCent and DRail are significant only in model $L O G$. Among significant location attributes measured in kilometers in model LIN, the highest coefficients are for
DNuis and DWater; the lowest is that for $D C B D$. At the same time the highest of the significant location coefficients in model $L O G$ is that for $D C B D$.

To investigate the existence of multicollinearity, we estimated the maximum of variance inflationary factors (VIF) (Table 3). The principle that VIF in excess of 10 (or tolerance lower than 0.10) indicates multicollinearity is usually used in the literature, see e.g. Seiler et al. (2001) and Des Rosiers et al. (2001). For models $L I N$ and $L O G$, the magnitudes of VIF are lower than the threshold that indicates no problem with multicollinearity.

Importantly, the values of the Moran's I sta-

Table 3. Estimated OLS results for the whole data set

\begin{tabular}{|c|c|c|c|c|}
\hline \multirow{2}{*}{$\begin{array}{l}\text { Variables and model } \\
\text { characteristics }\end{array}$} & \multicolumn{4}{|l|}{ Model } \\
\hline & $L I N$ & $L O G$ & LINDIR & LOGDIR \\
\hline Constant & $\begin{array}{l}3060.55 \\
(0.93)\end{array}$ & $\begin{array}{l}7.97 \\
(22.13)^{*}\end{array}$ & $\begin{array}{l}5226.95 \\
(1.55)\end{array}$ & $7.91(22.08)^{*}$ \\
\hline Floor1 & $\begin{array}{l}-1444.32 \\
(-1.69)\end{array}$ & $\begin{array}{l}-0.02 \\
(-0.70)\end{array}$ & $\begin{array}{l}-1498.37 \\
(-1.80)\end{array}$ & $-0.02(-0.62)$ \\
\hline FloorT & $\begin{array}{l}-1570.30 \\
(-1.77)\end{array}$ & $\begin{array}{l}-0.06 \\
(-2.27)^{*}\end{array}$ & $\begin{array}{l}-1851.60 \\
(-2.15)^{*}\end{array}$ & $-0.06(-2.13)^{*}$ \\
\hline Build & $\begin{array}{l}3284.04 \\
(4.75)^{*}\end{array}$ & $\begin{array}{l}0.15 \\
(6.53)^{*}\end{array}$ & $\begin{array}{l}3115.50 \\
(4.64)^{*}\end{array}$ & $0.15(6.48)^{*}$ \\
\hline Phone & $\begin{array}{l}1311.96 \\
(1.55)\end{array}$ & $\begin{array}{l}0.08 \\
(2.87)^{*}\end{array}$ & $\begin{array}{l}1098.97 \\
(1.35)\end{array}$ & $0.07(2.61)^{*}$ \\
\hline Area & $\begin{array}{l}478.44 \\
(7.59)^{*}\end{array}$ & $\begin{array}{l}0.65 \\
(7.24)^{*}\end{array}$ & $\begin{array}{l}461.50 \\
(7.24)^{*}\end{array}$ & $0.67(7.46)^{*}$ \\
\hline Balc & $\begin{array}{l}-528.53 \\
(-0.52)\end{array}$ & $\begin{array}{l}-0.01 \\
(-0.34)\end{array}$ & $\begin{array}{l}-915.68 \\
(-0.92)\end{array}$ & $-0.07(-0.14)$ \\
\hline Cond 2 & $\begin{array}{l}1312.06 \\
(1.17)\end{array}$ & $\begin{array}{l}0.02 \\
(0.60)\end{array}$ & $\begin{array}{l}1614.12 \\
(1.46)\end{array}$ & $0.02(0.64)$ \\
\hline Cond3 & $\begin{array}{l}1967.68 \\
(1.43)\end{array}$ & $\begin{array}{l}0.02 \\
(0.42)\end{array}$ & $\begin{array}{l}1990.26 \\
(1.43)\end{array}$ & $0.02(0.33)$ \\
\hline Cond4 & $\begin{array}{l}2026.70 \\
(1.75)\end{array}$ & $\begin{array}{l}0.04 \\
(1.11)\end{array}$ & $\begin{array}{l}2204.50 \\
(1.94)\end{array}$ & $0.04(1.25)$ \\
\hline Cond5 & $\begin{array}{l}2266.53 \\
(2.10)^{*}\end{array}$ & $\begin{array}{l}0.05 \\
(1.58)\end{array}$ & $\begin{array}{l}2321.35 \\
(2.17)^{*}\end{array}$ & $0.06(1.78)$ \\
\hline Cond6 & $\begin{array}{l}4600.19 \\
(2.76)^{*}\end{array}$ & $\begin{array}{l}0.13 \\
(2.50)^{*}\end{array}$ & $\begin{array}{l}4615.75 \\
(2.79)^{*}\end{array}$ & $0.14(2.75)^{*}$ \\
\hline Cond7 & $\begin{array}{l}9713.48 \\
(6.18)^{*}\end{array}$ & $\begin{array}{l}0.30 \\
(6.08)^{*}\end{array}$ & $\begin{array}{l}9401.38 \\
(5.79)^{*}\end{array}$ & $0.31(6.36)^{*}$ \\
\hline
\end{tabular}




\begin{tabular}{|c|c|c|c|c|}
\hline \multirow{2}{*}{$\begin{array}{l}\text { Variables and model } \\
\text { characteristics }\end{array}$} & \multicolumn{4}{|l|}{ Model } \\
\hline & $L I N$ & $L O G$ & LINDIR & LOGDIR \\
\hline \multicolumn{5}{|l|}{ (continued) } \\
\hline$D C B D$ & $\begin{array}{l}-828.21 \\
(-6.72)^{*}\end{array}$ & $\begin{array}{l}-0.24 \\
(-10.24)^{*}\end{array}$ & $\begin{array}{l}-1935.77 \\
(-7.66)^{*}\end{array}$ & $-0.23(-6.82)^{*}$ \\
\hline DSCent & $\begin{array}{l}-47.62 \\
(-0.23)\end{array}$ & $\begin{array}{l}-0.05 \\
(-4.91)^{*}\end{array}$ & $\begin{array}{l}-196.67 \\
(-0.87)\end{array}$ & $-0.04(-3.47)^{*}$ \\
\hline DStop & $\begin{array}{l}-2864.50 \\
(-1.36)\end{array}$ & $\begin{array}{l}-0.01 \\
(-0.34)\end{array}$ & $\begin{array}{l}-5975.94 \\
(-2.90)^{*}\end{array}$ & $-0.00(-0.26)$ \\
\hline DRail & $\begin{array}{l}-37.42 \\
(-0.41)\end{array}$ & $\begin{array}{l}-0.11 \\
(-5.44)^{*}\end{array}$ & $\begin{array}{l}303.53 \\
(2.30)^{*}\end{array}$ & $-0.11(-4.25)^{*}$ \\
\hline DWater & $\begin{array}{l}-1702.60 \\
(-3.79)^{*}\end{array}$ & $\begin{array}{l}-0.01 \\
(-0.37)\end{array}$ & $\begin{array}{l}-299.82 \\
(-0.58)\end{array}$ & $-0.01(-0.93)$ \\
\hline DNuis & $\begin{array}{l}2816.35 \\
(3.80)^{*}\end{array}$ & $\begin{array}{l}0.03 \\
(1.54)\end{array}$ & $\begin{array}{l}3184.94 \\
(4.18)^{*}\end{array}$ & $0.03(1.29)$ \\
\hline Prest & $\begin{array}{l}4761.57 \\
(5.97)^{*}\end{array}$ & $\begin{array}{l}0.09 \\
(2.74)^{*}\end{array}$ & $\begin{array}{l}2453.18 \\
(2.77)^{*}\end{array}$ & $0.08(2.01)^{*}$ \\
\hline$N \cdot D C B D$ & - & - & $\begin{array}{l}737.47 \\
(2.91)^{*}\end{array}$ & $0.01(0.35)$ \\
\hline$S \cdot D C B D$ & - & - & $\begin{array}{l}-61.76 \\
(-0.52)\end{array}$ & $-0.03(-1.56)$ \\
\hline$W \cdot D C B D$ & - & - & $\begin{array}{l}746.62 \\
(5.01)^{*}\end{array}$ & $-0.04(-1.74)$ \\
\hline Observations & 325 & 325 & 325 & 325 \\
\hline Adjusted R2 & 0.69 & 0.77 & 0.71 & 0.77 \\
\hline F-value & 39.76 & 57.47 & 37.76 & 50.20 \\
\hline Max $V I F$ & $\begin{array}{l}4.6 \\
(D C B D)\end{array}$ & $\begin{array}{l}3.7 \\
(D C B D)\end{array}$ & $\begin{array}{l}20.2 \\
(D C B D)\end{array}$ & 6.1 (DCBD) \\
\hline Moran's I & 7.36 & 3.60 & 6.49 & 3.74 \\
\hline
\end{tabular}

Note: White heteroskedastic consistent estimates. $t$-statistics are in parentheses below the coefficients. The asterisk indicates significance at the $5 \%$ level.

tistic are quite large; this suggests that neither model captures the underlying spatial relationship very well. As an alternative, we consider spatial models to incorporate the spatial structure into the analysis (Anselin, 1988 is the standard reference documenting these models). We have estimated two different kinds of spatial regression models to correct for the underlying spatial relationship. These are a spatial autoregressive model and a spatial error model. The results for the spatial models are presented in the Appendix. Even though the coefficient for spatial dependency is highly significant, none of the estimates for the loca- tion variables change dramatically. None of them are significantly different from the results of the OLS model. Hence, we use the OLS estimates in our econometric analysis.

As in Söderberg and Janssen (2001), we analyse whether the CBD accessibility affects the asking price differently in different geographical directions. We divide Donetsk into four parts, North, East, South, and West, with the CBD as the origin, to carry this out. Considering that the area to the east of the CBD is the most prestigious area outside the city centre, area East is used as the default area. So, we introduce three dummies for location 
in the hedonic price equation, North, South, and West, namely $N, S$, and $W$ respectively. The new variables are obtained by multiplying these dummies with $D C B D$. That is, we create interaction variables between distance to the CBD and geographical directions and thereby investigate whether the distance gradients depend on directions.

In Table 3, the new models are labelled LINDIR and LOGDIR. Whereas the results of model $L O G D I R$ are very close to $L O G$, the coefficients and even statistical significance of coefficients for location variables in LINDIR differ from those in LIN. For example, DStop and DRail become significant and DWater becomes insignificant in model LINDIR. However, the resulting effects of the CBD accessibility, i.e. the sums of the effects from $D C B D$ and each of the variables $N \cdot D C B D, S \cdot D C B D$, and $W \cdot D C B D$, are negative and significantly different from zero for the linear as well as for the log-linear model. At the same time, $W \cdot D C B D$ and $N \cdot D C B D$ are positive and significant in the linear model, whereas $D C B D$ is negative. The interpretation is that the western and northern directions are more desirable than the southern and eastern directions. For the northern location, this can be explained by the existence of a prestigious area. For the western location, the result is unexpected. One possible explanation might be that distances from the $\mathrm{CBD}$ in this direction are the longest, and therefore each additional kilometre is not as important as in other directions. The log-linear model takes care of this problem to some degree. In model LINDIR, VIF for DCBD is higher than 10, but this is expected as the distance to the CBD is highly correlated with itself.

We can compare the impact of one of the independent variables on change in the dependent variable. The easiest way is to check the dummy variable Prest. If Prest is equal to 1 in model $L I N$, the price increases by 4,762 USD. For a logarithmic functional form, the coefficient for a dummy variable is not interpreted as the percentage impact on price of a change in the dummy variable from zero to one. The correct expression for this percentage impact is $\mathrm{e}^{\beta}-1$ (Halvorsen and Palmquist, 1980). Thus, in model $L O G$, the price increases by 9.4 percent. It means that average asking price, which is equal to 21,103 USD for the non-prestigious area should be increased by 1,984 USD. The magnitudes of 4,762 USD and 1,984 USD differ. However, the corresponding magnitudes in LINDIR and LOGDIR, i.e. 2,453 USD and 1,688 USD are more similar.

In hedonic practice, models are often estimated not only for the overall market, but for geographical sub-markets as well (Hoesli et al., 1997; Fletcher et al., 2000; Berry et al., 2003 for example). To further investigate geographical differences in location variables we can split the sample into two different groups. The first group consists of apartments located within the central administrative district, and the second group of apartments outside it. For the first group, the models are labelled LIN_Cent and $L O G \_C e n t$ and for the second group, the models are labelled LIN_Out and LOG_Out. The results are shown in Table 4.

The relatively small number of observations in models LIN_Cent and LOG_Cent leads to low adjusted $R^{2}$ and high maximum VIF, which is, however, lower than the threshold value. For models LIN_Out and LOG_Out, the statistical characteristics are better. For example, the adjusted $R^{2}$ for the former model is the same as that for LIN.

Watkins (2001) presents a valuable review of the identification of housing sub-markets. According to him, the most common procedure introduced by Schnare and Struyk (1976) includes a Chow-test and a weighted standard error (WSE) calculation.

A Chow-test is applied to check the hypothesis of statistically stable estimated parameters in sub-samples. For the linear and log-linear specifications, we obtain $\mathrm{F}=6.66$ and $\mathrm{F}=3.57$ 
Table 4. Estimated OLS results for split data sets

\begin{tabular}{|c|c|c|c|c|}
\hline \multirow{2}{*}{$\begin{array}{l}\text { Variables and model } \\
\text { characteristics }\end{array}$} & \multicolumn{4}{|l|}{ Model } \\
\hline & $L I N$ & $L O G$ & LINDIR & LOGDIR \\
\hline Constant & $\begin{array}{l}61749.39 \\
(2.21)^{*}\end{array}$ & $\begin{array}{l}9.05 \\
(7.07)^{*}\end{array}$ & $\begin{array}{l}10514.59 \\
(3.50)^{*}\end{array}$ & $\begin{array}{l}8.88 \\
(18.65)^{*}\end{array}$ \\
\hline Floor1 & $\begin{array}{l}-7739.64 \\
(-2.28)^{*}\end{array}$ & $\begin{array}{l}-0.20 \\
(-2.24)^{*}\end{array}$ & $\begin{array}{l}-240.10 \\
(-0.33)\end{array}$ & $\begin{array}{l}-0.01 \\
(-0.22)\end{array}$ \\
\hline FloorT & $\begin{array}{l}-2934.34 \\
(-1.48)\end{array}$ & $\begin{array}{l}-0.10 \\
(-1.84)\end{array}$ & $\begin{array}{l}-987.30 \\
(-1.38)\end{array}$ & $\begin{array}{l}-0.05 \\
(-1.60)\end{array}$ \\
\hline Build & $\begin{array}{l}6897.53 \\
(2.65)^{*}\end{array}$ & $\begin{array}{l}0.16 \\
(2.22)^{*}\end{array}$ & $\begin{array}{l}3741.82 \\
(5.77)^{*}\end{array}$ & $\begin{array}{l}0.20 \\
(7.71)^{*}\end{array}$ \\
\hline Phone & $\begin{array}{l}-186.15 \\
(-0.06)\end{array}$ & $\begin{array}{l}0.04 \\
(0.50)\end{array}$ & $\begin{array}{l}998.89 \\
(1.50)\end{array}$ & $\begin{array}{l}0.06 \\
(2.18)^{*}\end{array}$ \\
\hline Area & $\begin{array}{l}566.02 \\
(4.80)^{*}\end{array}$ & $\begin{array}{l}0.86 \\
(4.81)^{*}\end{array}$ & $\begin{array}{l}363.13 \\
(6.07)^{*}\end{array}$ & $\begin{array}{l}0.43 \\
(3.53)^{*}\end{array}$ \\
\hline Balc & $\begin{array}{l}-2287.85 \\
(-1.08)\end{array}$ & $\begin{array}{l}-0.05 \\
(-0.80)\end{array}$ & $\begin{array}{l}-597.10 \\
(-0.86)\end{array}$ & $\begin{array}{l}-0.00 \\
(-0.08)\end{array}$ \\
\hline Cond2 & $\begin{array}{l}-205.56 \\
(-0.06)\end{array}$ & $\begin{array}{l}-0.01 \\
(-0.11)\end{array}$ & $\begin{array}{l}828.44 \\
(0.77)\end{array}$ & $\begin{array}{l}0.02 \\
(0.46)\end{array}$ \\
\hline Cond3 & $\begin{array}{l}1792.23 \\
(0.38)\end{array}$ & $\begin{array}{l}0.04 \\
(0.33)\end{array}$ & $\begin{array}{l}1349.33 \\
(0.92)\end{array}$ & $\begin{array}{l}0.02 \\
(0.31)\end{array}$ \\
\hline Cond4 & $\begin{array}{l}1239.57 \\
(0.38)\end{array}$ & $\begin{array}{l}0.01 \\
(0.07)\end{array}$ & $\begin{array}{l}473.89 \\
(0.46)\end{array}$ & $\begin{array}{l}0.04 \\
(1.04)\end{array}$ \\
\hline Cond5 & $\begin{array}{l}-751.75 \\
(-0.23)\end{array}$ & $\begin{array}{l}-0.04 \\
(-0.43)\end{array}$ & $\begin{array}{l}1899.72 \\
(1.90)\end{array}$ & $\begin{array}{l}0.09 \\
(2.21)^{*}\end{array}$ \\
\hline Cond6 & $\begin{array}{l}9885.78 \\
(2.28)^{*}\end{array}$ & $\begin{array}{l}0.22 \\
(1.85)\end{array}$ & $\begin{array}{l}2603.74 \\
(2.01)^{*}\end{array}$ & $\begin{array}{l}0.12 \\
(2.25)^{*}\end{array}$ \\
\hline Cond7 & $\begin{array}{l}7147.54 \\
(1.44)\end{array}$ & $\begin{array}{l}0.15 \\
(1.17)\end{array}$ & $\begin{array}{l}9219.21 \\
(6.42)^{*}\end{array}$ & $\begin{array}{l}0.33 \\
(5.79)^{*}\end{array}$ \\
\hline$D C B D$ & $\begin{array}{l}-6260.55 \\
(-2.55)^{*}\end{array}$ & $\begin{array}{l}-0.13 \\
(-2.06)^{*}\end{array}$ & $\begin{array}{l}-612.39 \\
(-5.64)^{*}\end{array}$ & $\begin{array}{l}-0.31 \\
(-10.65)^{*}\end{array}$ \\
\hline DSCent & $\begin{array}{l}-1136.12 \\
(-0.28)\end{array}$ & $\begin{array}{l}-0.12 \\
(-0.44)\end{array}$ & $\begin{array}{l}-794.80 \\
(-3.75)^{*}\end{array}$ & $\begin{array}{l}-0.04 \\
(-3.46)^{*}\end{array}$ \\
\hline DStop & $\begin{array}{l}3523.89 \\
(0.40)\end{array}$ & $\begin{array}{l}0.01 \\
(0.09)\end{array}$ & $\begin{array}{l}2757.43 \\
(1.58)\end{array}$ & $\begin{array}{l}0.01 \\
(0.54)\end{array}$ \\
\hline DRail & $\begin{array}{l}-5185.56 \\
(-1.84)\end{array}$ & $\begin{array}{l}-0.83 \\
(-1.48)\end{array}$ & $\begin{array}{l}-217.81 \\
(-2.43)^{*}\end{array}$ & $\begin{array}{l}-0.08 \\
(-3.95)^{*}\end{array}$ \\
\hline DWater & $\begin{array}{l}8017.64 \\
(1.00)\end{array}$ & $\begin{array}{l}0.07 \\
(0.93)\end{array}$ & $\begin{array}{l}-1442.20 \\
(-3.28)^{*}\end{array}$ & $\begin{array}{l}-0.04 \\
(-2.03)^{*}\end{array}$ \\
\hline DNuis & $\begin{array}{l}-4839.16 \\
(-0.83)\end{array}$ & $\begin{array}{l}-0.12 \\
(-0.54)\end{array}$ & $\begin{array}{l}724.51 \\
(0.99)\end{array}$ & $\begin{array}{l}0.03 \\
(1.72)\end{array}$ \\
\hline Prest & - & - & $\begin{array}{l}2282.15 \\
(3.01)^{*}\end{array}$ & $\begin{array}{l}0.06 \\
(2.02)^{*}\end{array}$ \\
\hline Observations & 75 & 75 & 250 & 250 \\
\hline Adjusted $\mathrm{R}^{2}$ & 0.47 & 0.47 & 0.69 & 0.73 \\
\hline F-value & 4.63 & 4.70 & 30.74 & 36.80 \\
\hline Max VIF & $\begin{array}{l}8.9 \\
\text { (DRail) }\end{array}$ & $\begin{array}{l}9.0 \\
(\text { DRail })\end{array}$ & $\begin{array}{l}4.0 \\
\text { (DRail) }\end{array}$ & $\begin{array}{l}3.4 \\
\text { (Cond5) }\end{array}$ \\
\hline
\end{tabular}

Note: In models LIN_Cent and LOG_Cent, Prest is equal to 1 for all apartments. 
respectively, both are larger than the critical value of 1.57 at the $5 \%$ significance level.

WSE for sub-samples in total is calculated using the formula

$$
W S E=\frac{\sum_{i=1}^{m}\left(\left(n_{i}-k_{i}-1\right) \cdot S E_{i}\right)}{\sum_{i=1}^{m}\left(n_{i}-k_{i}-1\right)},
$$

where: $n$ is the number of observations; $k$ is the number of explanatory variables; $i$ is the count for sub-samples; $m$ is the number of subsamples; $S E_{i}$ is the standard error in the $i$-th sub-sample model.

The results of WSE estimations are presented and compared with the initial models in Table 5. For linear specifications, the reduction in the standard error is 17 percent, whereas for log-linear specifications it is only 8 percent. According to literature review by Watkins (2001), either 5 percent or 10 percent cut off is employed without a strict guidance on the size of the reduction. In our case, the sub-market specifications in a linear form satisfy both thresholds, while the log-linear models satisfy only the former one.

Thus, Chow-test and WSE estimation indicate that two delineated sub-markets are different and cannot be described by one hedonic model. There are some interesting findings when it comes to the location variables. $D C B D$ is the only significant location variable in mod- els LIN_Cent and LOG_Cent and the coefficient for DSCent is smaller than that for DCBD. For the linear model the former is 5.5 times smaller than the latter. In models LIN_Out and $L O G_{-}$Out, all the location variables except DStop and DNuis are significant. LIN_Out is the only linear model where DSCent is significant. In this model, the coefficient for DSCent is higher than that for $D C B D$; the coefficient for DWater is 2.4 times higher than that for $D C B D$. The remarkable point is the comparison of the coefficients for DCBD in LIN_Cent and LIN_Out. For central locations, it is more than 10 times higher than that for locations outside the centre. At the same time, in model $L O G \_O u t$ the coefficient for $D C B D$ is the highest among coefficients for the location variables. For central locations, the insignificant variables DWater and DNuis have unexpected signs. This might be explained by the high density of buildings, which are barriers for the influence of water, green areas and nuisance objects.

Though there are dissimilarities between the linear and log-linear models concerning the importance of secondary centres, it seems that these centres in Donetsk are important. Therefore, Donetsk can be considered as a nonmonocentric city. The difference between nonmonocentric and polycentric urban models is described e.g. in Sivitanidou (1997). Here we do not investigate this difference, but conclude that a monocentric model is not appropriate for Donetsk.

Table 5. Weighted standard error tests

\begin{tabular}{lll}
\hline Model & Standard error & Percent reduction \\
\hline Linear specifications: & 5479 & \\
LIN & 4538 & 17 \\
LIN_Cent and LIN_Out & & \\
Log-linear specifications: & 0.175904 & \\
LOG & 0.162333 & 8 \\
LOG_Cent and LOG_Out &
\end{tabular}




\section{ESTIMATION OF WEIGHTS AND COMPARISON WITH EXPERT VALUATIONS}

The focus of the paper is on location attributes and their impact on apartment prices in Donetsk. We can extract the relative weights of the location variables and compare them with previous findings for this city. For this it is easier to use a linear model.

The relative importance in linear regression is quite often discussed in scientific literature. As the choice of one or another concept of relative importance often affects conclusions (Kruskal and Majors, 1989), it is important to select a meaningful measure for our task. It can be the regression coefficient, the standardized regression coefficient, the contribution to $R^{2}$ or a more complex measure (Bring, 1994; Thomas et al., 1998; Johnson, 2000; Johnson and Lebreton, 2004).

The standardized regression coefficient (or beta coefficient) is much criticized in the statistics literature (e.g. Darlington, 1990; Bring, 1994). This measure is a mixture of the estimated effect and the standard deviation, which should be analysed separately (King, 1986).

The unstandardized regression coefficient is more appropriate for a comparison of variables, which have the same unit of measurement. We restrict the comparison of location attributes to the distance variables, all of which are measured in kilometres and which are therefore comparable in nature. Thus, though WTP for Prest is the highest among the location attributes, that dummy variable is not considered in the comparison.

We suppose that the relative importance of distance variables estimated with the use of unstandardized coefficients is transparent. Therefore, more complex measurements of weights are not applied in this study.

Among the linear models specified above it would be better to focus on LIN_Cent and LIN_Out. However, due to the small number of observations and only one significant location variable $(D C B D)$ in $L I N \_C e n t$ we only use LIN_Out. Model LIN is also exploited to obtain the complete picture of the relative importance of location attributes.

In Table 6, we show the weights of significant distance attributes calculated with the method proposed in Kryvobokov (2004). The weights are estimated on the basis of the absolute values of the regression coefficients, i.e. marginal WTP. Negative coefficients and their weights are shown in grey.

According to the overview of generations of residential property valuation methods made by Kauko (2004), given a recent "revitalisation" of more qualitative valuation methodology, subjective judgement is accepted as at least as

Table 6. Estimation of weights from the regression models

\begin{tabular}{|c|c|c|c|c|}
\hline \multirow[t]{2}{*}{ Location variables } & \multicolumn{2}{|l|}{ LIN } & \multicolumn{2}{|l|}{ LIN_Out } \\
\hline & WTP & Weight & WTP & Weight \\
\hline$D C B D$ & -828.21 & 0.15 & -612.39 & 0.20 \\
\hline DSCent & $\mathrm{N} / \mathrm{s}$ & 0.00 & -794.80 & 0.26 \\
\hline DStop & $\mathrm{N} / \mathrm{s}$ & 0.00 & $\mathrm{~N} / \mathrm{s}$ & 0.00 \\
\hline DRail & $\mathrm{N} / \mathrm{s}$ & 0.00 & -217.81 & 0.07 \\
\hline DWater & -1702.60 & 0.32 & -1442.20 & 0.47 \\
\hline DNuis & 2816.35 & 0.53 & $\mathrm{~N} / \mathrm{s}$ & 0.00 \\
\hline Sum of absolute values & 5347.16 & 1.00 & 3067.20 & 1.00 \\
\hline
\end{tabular}

Note: N/s - statistically not significant. 
valid an indicator as variables based on population censuses, measured distances etc. It should be fruitful to compare the results of expert valuations with the regression outcomes presented above. Analysing the same housing market, using the same location variables and assuming that the relative importance is correctly estimated, it is possible to compare the results from different studies.

Table 7 exhibits the weights of the location attributes estimated for Donetsk in Kryvobokov (2005a) using expert valuation methods: the AHP and the direct questionnaire. Four groups of respondents were selected, namely valuers, realtors, urban planners, and land managers. The intention was to select the best experts in the subject. These experts evaluated the relative importance of the location attributes of apartments. The hy- pothesis that the mean is equal to zero was rejected for all these location variables at the 5\% significance level. In Table 7, the derived weights are recalculated to include only the attributes corresponding to location variables from models LIN and LIN_Out. The units of measurement in the regression models and the expert valuations are the same for the majority of variables. The two exceptions in expert valuation methods are the attributes for the distance to a public transportation stop and the distance to water and green area, which were measured in hundreds of meters; therefore they are named dStop and dWater in the tables below. In order to compare weights having the same units of measurement we can recalculate the weights from Table 6 as if distance to water was measured in hundreds of meters. Linear models allow making such cal-

Table 7. Estimation of weights from expert valuations from Kryvobokov (2005a)

\begin{tabular}{lllll}
\hline \multirow{2}{*}{ Location variables } & AHP & \multicolumn{2}{l}{ Direct questionnaire } \\
\cline { 2 - 5 } & Initial weight & Recalculated weight & Initial weight & Recalculated weight \\
\hline DCBD & 0.14 & 0.26 & 0.17 & 0.35 \\
DSCent & 0.10 & 0.19 & 0.10 & 0.21 \\
dStop & 0.08 & 0.15 & 0.04 & 0.08 \\
DRail & 0.02 & 0.04 & 0.02 & 0.04 \\
dWater & 0.06 & 0.11 & 0.07 & 0.15 \\
DNuis & 0.13 & 0.25 & 0.08 & 0.17 \\
Sum & 0.53 & 1.00 & 0.48 & 1.00 \\
\hline
\end{tabular}

Table 8. Comparison of recalculated weights

\begin{tabular}{lllllll}
\hline $\begin{array}{l}\text { Location } \\
\text { variables }\end{array}$ & LIN & LIN_Out & AHP & $\begin{array}{l}\text { Direct } \\
\text { questionnaire }\end{array}$ & $\begin{array}{l}\text { Std.dev.- to- } \\
\text { average ratio }\end{array}$ & Max. difference \\
\hline DCBD & 0.22 & 0.35 & 0.26 & 0.35 & 0.22 & 0.13 \\
DSCent & 0.00 & 0.45 & 0.19 & 0.21 & 0.87 & 0.45 \\
dStop & 0.00 & 0.00 & 0.15 & 0.08 & 1.26 & 0.15 \\
DRail & 0.00 & 0.12 & 0.04 & 0.04 & 1.01 & 0.12 \\
dWater & 0.04 & 0.08 & 0.11 & 0.15 & 0.49 & 0.11 \\
DNuis & 0.74 & 0.00 & 0.25 & 0.17 & 1.10 & 0.74 \\
\hline
\end{tabular}


culations. The recalculated weights from two regression models and two expert valuation methods are demonstrated in Table 8. Ratios of standard deviation to average as well as maximum differences are calculated for these four results.

Comparison of weights in Table 8 highlights the following. The variables $D C B D$ and $d$ Water have the lowest standard deviation-to-average ratios and low absolute differences, i.e. maximum differences. According to the experts, $D C B D$ has the highest weight (though DNuis in the AHP has almost the same magnitude). According to market valuation, either DNuis or DSCent has the highest weight. DStop (and consequently $d S t o p$ ) is insignificant in the considered hedonic models, but according to expert valuations, $d$ Stop has weights higher than DRail. The highest standard deviation-to-average ratios are those for $d S t o p$ and DNuis that can be explained by zero weights in regression results. The same explanation is true for high absolute differences for DNuis and DSCent.

\section{CONCLUSIONS}

Our main findings can be summarised as follows. Each location variable is significant in at least one of the reported regression models. The only variables significant in all models are distance to the CBD and location in a prestigious area. The least important location attribute is distance to a public transportation stop. The experiments with distance gradients illustrated that western and northern directions from the CBD are more attractive than southern and eastern directions. Apartments located in the city centre and outside of it are different sub-markets according to Chow-tests and weighted standard error estimations. For centrally located apartments, the only important location attribute is the distance to the $\mathrm{CBD}$, whereas for locations outside the city centre the other location attributes, such as distance to water and green area or to the near- est secondary centre may be of more importance. The coefficient for distance to the CBD is always negative; the same is true for distance to a secondary centre.

The result of the comparison of the regression models to the expert valuations includes the following findings. According to regression results, distance to nuisance or to the nearest secondary centre may be more important than experts supposed. Moreover, the weights of these attributes may be higher than that of distance to the CBD, which has the highest weight in expert valuations. Distance to a public transportation stop, evaluated quite high by the experts, is not significant in hedonic models.

Regression results concerning the accessibility of water objects and green areas are generally similar to expert valuations. When this variable is measured with the same unit of measurement as other location attributes (as in regression models), we see the signal that consumer preferences in respect to water objects and green areas are stronger than that in respect to the CBD and secondary centres. This signal should be accepted in context of development policy.

The specification of a model for urban land assessment in Donetsk should include all the location variables examined in the reported hedonic models for apartment prices; the only exception might be distance to a public transportation stop. The estimation of the weights of relative importance highlights that the attribute of distance to water and green area should have a weight higher than the CBD accessibility. Further research about the specification of the model should include such items as distance to shops, crime rate, and traffic noise.

The fact that apartment prices can be explained by apartment attributes and location attributes is an indication that the Donetsk apartment market is a well-functioned market. The included attributes have both signs 
and magnitudes in line with results in studies carried out in Western Europe and North America. Furthermore, as the distances to secondary centres are capitalised into the apartment prices, it seems that Donetsk is a nonmonocentric city.

To detect local peculiarities, one could apply Geographically Weighted Regression (e.g. Brunsdon et al., 1996), which is becoming a more and more popular technique in real estate studies (e.g. Borst, 2006; Des Rosiers and Thériault, 2006). The application of local regression modelling in Donetsk merits future research.

\section{Acknowledgements}

The authors thank Professors Hans Mattsson, Hans Lind, and Roland Andersson at Royal Institute of Technology, Stockholm for general supervision and comments. The Department of Master Plan of Donetsk has provided the considerable amount of data, for which the authors are very grateful. The Swedish Institute has provided finance for the research that is highly appreciated. We also thank the anonymous referees for their valuable remarks and comments.

\section{REFERENCES}

Anselin, L. (1988) Spatial Econometrics: Methods and Models, Dordecht: Kluwer.

Asabere, P. K. and Huffman, F. E. (1996) Thoroughfares and Apartment Values. Journal of Real Estate Research, 12(1), p. 9-16.

Berry, J., McGreal, S., Stevenson, S., Young, J. and Webb, J. R. (2003) Estimation of Apartment Submarkets in Dublin, Ireland. Journal of Real Estate Research, 25(2), p. 159-170.

Bible, D. S. and Hsieh, C. (1999) Determinants of Vacant Land Values and Implications for Appraisers. The Appraisal Journal, LXVII(3), p. 264-268.

Björklund, K. and Klingborg, K. (2005) Correlation between Negotiated Rents and Neighbourhood
Quality: A Case Study of Two Cities in Sweden. Housing Studies, 20(4), p. 627-648.

Bogdon, A. S. and Can, A. (1997) Indicators of Local Housing Affordability: Comparative and Spatial Approaches. Real Estate Economics, 25(1), p. 43-80.

Borst, R. A. (2006) The Comparable Sales Method as the Basis for a Property Tax Valuation System and its Relationship and Comparison to Geostatistical Valuation Models. Paper in the International congress "Advances in mass appraisal methods", Delft University of Technology, $19 \mathrm{p}$.

Boyle, M. A. and Kiel, K. A. (2001) A Survey of House Price Hedonic Studies of the Impact of Environmental Externalities. Journal of Real Estate Literature, 9(2), p. 117-144.

Branas-Garza, P., Rodero Cosano, J. and Presley, J. R. (2002) The North-South divide and house price islands: the case of Córdoba (Spain). European Journal of Housing Policy, 2(1), p. 45-63.

Bring, J. (1994) How to Standardize Regression Coefficients. American Statistician, 48(3), p. 209213.

Brunsdon, C. F., Fotheringham, A. S. and Charlton, M. E. (1996) Geographically Weighted Regression: A Method for Exploring Spatial Nonstationarity. Geographical Analysis, 28(4), p. 281-298.

Colwell, P. F. (1990) Power Lines and Land Value. Journal of Real Estate Research, 5(1), p. 117127.

Cornia, G. C. and Slide, B. A. (2005) Property Taxation of Multifamily Housing: An Empirical Analysis of Vertical and Horizontal Equity. Journal of Real Estate Research, 27(1), p. 1746.

Costello, G. and Watkins, C. (2002) Towards a System of Local House Price Indices. Housing Studies, 17(6), p. 857-873.

Darlington, R. (1990) Regression and Linear Models, New York: McGraw-Hill.

De Cesare, C. M. and Ruddock, L. (1998) A New Approach to the Analysis of Assessment Equity. Assessment Journal, 5(2), p. 57-69.

De Graaff, T., Florax, R. J. G. M., Nijkamp, P. and Reggiani, A. (2001) A general misspecification test for spatial regression model: dependence, heterogeneity, and nonlinearity. Journal of Regional Science, 41(2), p. 255-276. 
Des Rosiers, F., Lagana, A. and Thériault, M. (2001) Size and proximity effects of primary schools on surrounding house values. Journal of Property Research, 18(2), p. 149-168.

Des Rosiers, F. and Thériault, M. (2006) Mass Appraisal, Hedonic Price Modelling and Urban Externalities: Understanding Property Value Shaping Process. Paper in the International congress "Advances in mass appraisal methods", Delft University of Technology, 40 p.

Dubin, R. A. (1998) Spatial Autocorrelation: A Primer. Journal of Housing Economics, 7(4), p. 304-327.

Dubin, R., Pace, R. K. and Thibodeau, T. G. (1999) Spatial Autoregression Techniques for Real Estate Data. Journal of Real Estate Literature, 7(1), p. 79-95.

Fletcher, M., Gallimore, P. and Mangan, J. The modelling of housing submarkets. Journal of Property Investment and Finance (2000), 18(4), p. 473-487.

Gloudemans, R. J. (2002) Comparison of Three Residential Regression Models: Additive, Multiplicative, and Nonlinear. Assessment Journal, 9(4), p. 25-36.

Halvorsen, R. and Palmquist, R. (1980) The interpretation of dummy variables in semilogarithmic equations. American Economic Review, 70(3), p. 474-475.

Halvorsen, R. and Pollakowski, H. O. (1981) Choice of functional form for hedonic price equations. Journal of Urban Economics, 10(1), p. 37-49.

Henneberry, J. (1999) Transport investment and house prices. Journal of Property Investment and Finance, 16(2), p. 144-158.

Hoesli, M., Thion, B. and Watkins, C. (1997) A hedonic investigation of the rental value of apartments in central Bordeaux, Journal of Property Research, 14(1), p. 15-26.

Janssen, C. and Söderberg, B. (1999) Estimating Market Prices and Assessed Values for Income Properties. Urban Studies, 36(2), p. 359-376.

Johnson, J. W. (2000) A Heuristic Method for Estimating the Relative Weight of Predictor Variables in Multiple Regression. Multivariate Behavioral Research, 35(1), p. 1-19.

Johnson, J. W. and Lebreton, J. M. (2004) History and Use of Relative Importance Indices in Organizational Research. Organizational Research Methods, 7 (3), p. 238-257.
Kauko, T. J. (2002) Modelling the locational determinants of house prices: neural network and value tree approaches, $\mathrm{PhD}$ thesis, Utrecht: Utrecht University.

Kauko, T. (2004) Towards the 4th generation - an essay on innovations in residential property value modelling expertise. Journal of Property Research, 21(1), p. 75-97.

King, G. (1986) How Not to Lie With Statistics: Avoiding Common Mistakes in Quantitative Political Science. American Journal of Political Science, 30(3), p. 666-687.

Kruskal, W. and Majors, R. (1989) Concepts of Relative Importance in Recent Scientific Literature. American Statistician, 43(1), p. 2-6.

Kryvobokov, M. (2004) Urban land zoning for taxation purposes in Ukraine: Possible methods under an immature land market. Property $\mathrm{Ma}$ nagement, 22(3), p. 214-229.

Kryvobokov, M. (2005a) Estimating the weights of location attributes with the Analytic Hierarchy Process in Donetsk, Ukraine. Nordic Journal of Surveying and Real Estate Research, 2(2), p. 7-31.

Kryvobokov, M. (2005b) Formalisation of urban land value zoning with application of GIS-model, Candidate of Science thesis, Department of Geoinformatics and Geodesy, Donetsk National Technical University, 147 p. (In Ukrainian).

O'Connor, P. M. (2002) Comparison of Three Residential Regression Models: Additive, Multiplicative, and Nonlinear. Assessment Journal, 9(4), p. $37-43$.

Pace, R. K., Barry, R. and Sirmans, C. F. (1998) Spatial Statistics and Real Estate. Journal of Real Estate Finance and Economics, 17(1), p. 5-13.

Pavlov, A. D. (2000) Space-Varying Regression Coefficients: A Semi-parametric Approach Applied to Real Estate Markets. Real Estate Economics, 28(2), p. 249-283.

Roseman, G. (2002) The Real Estate Market in Kiev: History and Issues. Real Estate Issues, 27(2), p. 25-31.

Rosen, S. (1974) Hedonic prices and implicit markets: product differentiation in pure competition. Journal of Political Economy, 82, p. 3455.

Schnare, A. and Struyk, R. (1976) Segmentation in Urban Housing Markets. Journal of Urban Economics, 33(2), p. 146-166. 
Seiler, M. J., Bond, M. T. and Seiler, V. L. (2001) The Impact of World Class Great Lakes Water Views on residential Property Values. The Appraisal Journal, LXIX(3), p. 287-295.

Sirmans, G. S., Macpherson, D. A. and Zietz, E. N. (2005) The Composition of Hedonic Pricing Models. Journal of Real Estate Literature, 13(1), p. 3-43.

Sivets, S. A. (2001) Creation and practical application of multifactor hybrid model for valuation of income properties. Valuation Questions, 4, p. 27-36 (In Russian).

Sivets, S. A. and Levykina, I. A. (2003) Econometric modelling in real estate valuation, Zaporozhye: Poligraf, 220 p. (In Russian).

Sivitanidou, R. (1995) Urban Spatial Variations in Office-Commercial Rents: The Role of Spatial Amenities and Commercial Zoning. Journal of Urban Economics, 38 (1), p. 23-49.

Sivitanidou, R. (1996) Do Office-Commercial Firms Value Access to Service Employment Centers? A Hedonic Value Analysis within Polycentric Los Angeles. Journal of Urban Economics, 40 (2), p. 125-149.

Sivitanidou, R. (1997) Are Center Access Advantages Weakening? The Case of Office-Commercial Markets. Journal of Urban Economics, 42 (1), p. 79-97.

So, H. M., Tse, R. Y. C. and Ganesan, S. (1997) Estimating the influence of transport on house prices: evidence from Hong Kong. Journal of Property Valuation and Investment, 15 (1), p. 40-47.

Söderberg, B. and Janssen, C. (2001) Estimating Distance Gradients for Apartment Properties. Urban Studies, 38(1), p. 61-79.
Thomas, D. R., Hughes, E. and Zumbo, B. D. (1998) On Variable Importance in Linear Regression. Social Indicators Research, 45(1-3), p. 253-275.

Thomas, P. R. (2003) Asset Valuation Under Nonmarket Conditions in Transitional Economies: The Case of Ukraine. The Appraisal Journal, LXXI(4), p. 299-310.

Ward, R., Guilford, J., Jones, B., Pratt, D. and German, J. (2002) Piecing Together Location: Three Studies by the Lucas County Research and Development Staff. Assessment Journal, 9(5), p. $15-48$.

Watkins, C. (1998) Are new entrants to the residential property market informationally disadvantaged? Journal of Property Research, 15(1), p. $57-70$.

Watkins, C. (2001) The definition and identification of housing submarkets. Environment and Planning $A$, 33(12), p. 2235-2253.

Wilhelmsson, M. (2002) Spatial Models in Real Estate Economics. Housing, Theory and Society, 19 , p. $92-101$.

Wilhelmsson, M. (2004) A method to derive housing sub-markets and reduce spatial dependency. Property Management, 22(4), p. 276-288.

Wiltshaw, D. G. (1996) Spatial autocorrelation and valuation accuracy: a neglected methodological problem. Journal of Property Research, 13(4), p. 275-286.

Yang, Z. (2001) An application of the hedonic price model with uncertain attribute: The case of the People's Republic of China. Property Management, 19(1), p. 50-63.

\section{SANTRAUKA}

\section{VIETOS ATRIBUTU ANALIZE் SU HEDONISTINIU MODELIU SIEKIANT NUSTATYTI BUTU KAINAS DONECKE (UKRAINA)}

\section{Marko KRYVOBOKOV, Mats WILHELMSSON}

Apibrěžtas hedonistinis modelis, leidžiantis nustatyti butų kainas Donecke (Ukraina). Pagal ši modeli nustatomi statistiškai reikšmingi vietos atributai. Šiuos atributus galima naudoti vertinant sklypus mieste, kur trūksta duomenų apie žemès rinką. Nagrinejjami atstumo gradientai siekiant įvertinti prieigą prie centrinių verslo rajonų įvairiomis geografinėmis kryptimis. Sukurti modeliai bandomiesiems objektams, esantiems miesto centre ir už jo. Remiantis erdvès svorine matrica, nustatoma erdvès autokoreliacija. Regresijos rezultatai lyginami su ekspertu vertinimais. 


\section{APPENDIX}

Spatial Autoregressive Models (SAR) and Spatial Error Models (SEM)

\begin{tabular}{|c|c|c|c|c|c|}
\hline \multirow{3}{*}{$\begin{array}{l}\text { Variables and } \\
\text { model } \\
\text { characteristics }\end{array}$} & \multicolumn{5}{|l|}{ Model } \\
\hline & \multicolumn{2}{|l|}{ LOG } & \multicolumn{3}{|c|}{ LOGDIR } \\
\hline & SAR & SEM & SAR & SEM & \\
\hline Constant & $\begin{array}{l}8.97 \\
(9.04)^{*}\end{array}$ & $\begin{array}{l}8.15 \\
(21.76)^{*}\end{array}$ & $\begin{array}{l}6.12 \\
(9.18)^{*}\end{array}$ & $\begin{array}{l}8.09 \\
(21.74)^{*}\end{array}$ & \\
\hline Floor1 & $\begin{array}{l}-0.02 \\
(-0.82)\end{array}$ & $\begin{array}{l}-0.03 \\
(-0.99)\end{array}$ & $\begin{array}{l}-0.02 \\
(-0.77)\end{array}$ & $\begin{array}{l}-0.02 \\
(-0.90)\end{array}$ & \\
\hline FloorT & $\begin{array}{l}-0.06 \\
(-2.51)^{*}\end{array}$ & $\begin{array}{l}-0.06 \\
(-2.33)^{*}\end{array}$ & $\begin{array}{l}-0.06 \\
(-2.41)^{*}\end{array}$ & $\begin{array}{l}-0.05 \\
(-2.24)^{*}\end{array}$ & \\
\hline Build & $\begin{array}{l}0.14 \\
(6.11)^{*}\end{array}$ & $\begin{array}{l}0.16 \\
(6.59)^{*}\end{array}$ & $\begin{array}{l}0.14 \\
(6.14)^{*}\end{array}$ & $\begin{array}{l}0.16 \\
(6.58)^{*}\end{array}$ & \\
\hline Phone & $\begin{array}{l}0.07 \\
(2.77)^{*}\end{array}$ & $\begin{array}{l}0.06 \\
(2.54)^{*}\end{array}$ & $\begin{array}{l}0.07 \\
(2.57)^{*}\end{array}$ & $\begin{array}{l}0.06 \\
(2.33)^{*}\end{array}$ & \\
\hline Area & $\begin{array}{l}0.60 \\
(6.40)^{*}\end{array}$ & $\begin{array}{l}0.60 \\
(6.25)^{*}\end{array}$ & $\begin{array}{l}0.62 \\
(6.56)^{*}\end{array}$ & $\begin{array}{l}0.61 \\
(6.44)^{*}\end{array}$ & \\
\hline Balc & $\begin{array}{l}-0.01 \\
(-0.31)\end{array}$ & $\begin{array}{l}-0.01 \\
(-0.08)\end{array}$ & $\begin{array}{l}-0.01 \\
(-0.14)\end{array}$ & $\begin{array}{l}0.01 \\
(0.11)\end{array}$ & \\
\hline Cond2 & $\begin{array}{l}0.01 \\
(0.34)\end{array}$ & $\begin{array}{l}0.01 \\
(0.26)\end{array}$ & $\begin{array}{l}0.01 \\
(0.38)\end{array}$ & $\begin{array}{l}0.01 \\
(0.30)\end{array}$ & \\
\hline Cond3 & $\begin{array}{l}0.02 \\
(0.29)\end{array}$ & $\begin{array}{l}0.01 \\
(0.21)\end{array}$ & $\begin{array}{l}0.01 \\
(0.25)\end{array}$ & $\begin{array}{l}0.01 \\
(0.16)\end{array}$ & \\
\hline Cond4 & $\begin{array}{l}0.03 \\
(0.82)\end{array}$ & $\begin{array}{l}0.03 \\
(0.71)\end{array}$ & $\begin{array}{l}0.03 \\
(0.91)\end{array}$ & $\begin{array}{l}0.03 \\
(0.80)\end{array}$ & \\
\hline Cond5 & $\begin{array}{l}0.05 \\
(1.31)\end{array}$ & $\begin{array}{l}0.05 \\
(1.33)\end{array}$ & $\begin{array}{l}0.05 \\
(1.44)\end{array}$ & $\begin{array}{l}0.05 \\
(1.46)\end{array}$ & \\
\hline Cond6 & $\begin{array}{l}0.12 \\
(2.56)^{*}\end{array}$ & $\begin{array}{l}0.13 \\
(2.65)^{*}\end{array}$ & $\begin{array}{l}0.13 \\
(2.80)^{*}\end{array}$ & $\begin{array}{l}0.14 \\
(2.88)^{*}\end{array}$ & \\
\hline Cond7 & $\begin{array}{l}0.30 \\
(5.92)^{*}\end{array}$ & $\begin{array}{l}0.30 \\
(5.83)^{*}\end{array}$ & $\begin{array}{l}0.31 \\
(6.01)^{*}\end{array}$ & $\begin{array}{l}0.30 \\
(5.94)^{*}\end{array}$ & \\
\hline$D C B D$ & $\begin{array}{l}-0.19 \\
(-9.11)^{*}\end{array}$ & $\begin{array}{l}-0.23 \\
(-11.18)^{*}\end{array}$ & $\begin{array}{l}-0.18 \\
(-7.25)^{*}\end{array}$ & $\begin{array}{l}-0.21 \\
(-7.72)^{*}\end{array}$ & \\
\hline DSCent & $\begin{array}{l}-0.05 \\
(-4.26)^{*}\end{array}$ & $\begin{array}{l}-0.05 \\
(-4.04)^{*}\end{array}$ & $\begin{array}{l}-0.04 \\
(-3.26)^{*}\end{array}$ & $\begin{array}{l}-0.04 \\
(-2.84)^{*}\end{array}$ & \\
\hline DStop & $\begin{array}{l}-0.01 \\
(-0.32)\end{array}$ & $\begin{array}{l}-0.01 \\
(-0.62)\end{array}$ & $\begin{array}{l}-0.01 \\
(-0.22)\end{array}$ & $\begin{array}{l}-0.01 \\
(-0.52)\end{array}$ & \\
\hline DRail & $\begin{array}{l}-0.08 \\
(-4.32)^{*}\end{array}$ & $\begin{array}{l}-0.11 \\
(-4.86)^{*}\end{array}$ & $\begin{array}{l}-0.08 \\
(-3.56)^{*}\end{array}$ & $\begin{array}{l}-0.10 \\
(-4.01)^{*}\end{array}$ & \\
\hline DWater & $\begin{array}{l}-0.01 \\
(-0.36)\end{array}$ & $\begin{array}{l}-0.01 \\
(-0.68)\end{array}$ & $\begin{array}{l}-0.01 \\
(-0.87)\end{array}$ & $\begin{array}{l}-0.02 \\
(-1.27)\end{array}$ & \\
\hline & & & & & (continued) \\
\hline
\end{tabular}




\begin{tabular}{|c|c|c|c|c|}
\hline \multirow{3}{*}{$\begin{array}{l}\text { Variables and } \\
\text { model } \\
\text { characteristics }\end{array}$} & \multicolumn{4}{|l|}{ Model } \\
\hline & \multicolumn{2}{|l|}{ LOG } & \multicolumn{2}{|c|}{ LOGDIR } \\
\hline & SAR & SEM & SAR & SEM \\
\hline \multicolumn{5}{|l|}{ (continued) } \\
\hline DNuis & $\begin{array}{l}0.02 \\
(1.16)\end{array}$ & $\begin{array}{l}0.02 \\
(1.18)\end{array}$ & $\begin{array}{l}0.02 \\
(1.00)\end{array}$ & $\begin{array}{l}0.02 \\
(0.91)\end{array}$ \\
\hline Prest & $\begin{array}{l}0.09 \\
(2.87)^{*}\end{array}$ & $\begin{array}{l}0.10 \\
(2.82)^{*}\end{array}$ & $\begin{array}{l}0.07 \\
(2.17)^{*}\end{array}$ & $\begin{array}{l}0.08 \\
(2.09)^{*}\end{array}$ \\
\hline$N \cdot D C B D$ & - & - & $\begin{array}{l}0.01 \\
(0.35)\end{array}$ & $\begin{array}{l}0.01 \\
(0.12)\end{array}$ \\
\hline$S \cdot D C B D$ & - & - & $\begin{array}{l}-0.02 \\
(-1.00)\end{array}$ & $\begin{array}{l}-0.04 \\
(-1.55)\end{array}$ \\
\hline$W \cdot D C B D$ & - & - & $\begin{array}{l}-0.03 \\
(-1.60)\end{array}$ & $\begin{array}{l}-0.04 \\
(-2.07)^{*}\end{array}$ \\
\hline$\rho$ & $\begin{array}{l}0.21 \\
(3.74)^{*}\end{array}$ & - & $\begin{array}{l}0.19 \\
(3.31)^{*}\end{array}$ & - \\
\hline$\lambda$ & - & $\begin{array}{l}0.22 \\
(3.32)^{*}\end{array}$ & - & $\begin{array}{l}0.21 \\
(3.18)^{*}\end{array}$ \\
\hline Observations & 325 & 325 & 325 & 325 \\
\hline Adjusted $R^{2}$ & 0.77 & 0.78 & 0.77 & 0.78 \\
\hline
\end{tabular}

